\title{
Tourism economies and islands' resilience to the global financial crisis
}

\author{
Katarzyna Podhorodecka \\ Faculty of Geography and Regional Studies, University of Warsaw, Poland \\ kpodhorodecka@uw.edu.pl
}

\begin{abstract}
The article is a comparative study of islands' reactions to the global financial crisis. The main aim is to identify conditions which influence how the effects of the crisis in the tourism sector differed between selected island territories. Seventeen island territories which rely on tourism were selected for analysis. Each reacted differently to the global financial crisis, especially with regard to changes in tourist movement, employment in tourism, and expenditure by foreign tourists. The factors analysed are: length of time as an independent state or dependent territory, degree of dependence on tourism, the diversity of the mix of foreign markets from which tourists arrive, level of dominance of the main foreign market, level of dependence on European and North- and South American markets, duration of flights from the main market, level of economic development, quality of life of the island area's residents, tourist expenditure, and changes in government expenditure on tourism. The statistical analysis was conducted using both the Spearman and the Kendall rank correlation coefficients.
\end{abstract}

Keywords: global financial crisis, island economics, island territories, resilience, SIDS, tourism Economy

https://doi.org/10.24043/isj.43

(C) 2018 - Institute of Island Studies, University of Prince Edward Island, Canada.

\section{Introduction}

Tourism is the driving force of economic growth in many island economies that lack other competitive sectors. There are over 180,000 islands of different sizes and natural conditions worldwide (Tiago et al., 2016, pp. 601-618; Tiago et al., 2015). Many islands have good environmental conditions for expanding into the tourism market. However, the global financial crisis revealed the great vulnerability of island territories to external factors (Lewis et al., 2009, p. 2). Examples of severe problems associated with the global financial crisis include: decreases in the number of arrivals to Antigua and Barbuda; a decrease in the export of goods essential to the economy, such as bauxite and aluminium in Jamaica; and decreased remittances to islands (Lewis et al., 2009, p. 2). The analysis of the situation in island countries and dependent territories during the global financial crisis (2008-2010) showed that the economic situation of islands was varied. Despite the global recession in the tourism market, for some of the islands tourism movement (i.e. tourist numbers), tourist expenditure, and employment in tourism actually improved. Seventeen island areas worldwide whose tourism industry expenditure generates more than $10 \%$ of GDP were selected for analysis.

\section{Literature discussion}

Tourism, sometimes called the 'blue economy', is the main economic sector for many SIDS (Small Island Developing States). Many island territories are strictly reliant on tourism and, for 
many, tourism is the main source of exports (e.g. Maldives, Seychelles, Saint Lucia) (Reddyis, 2013). Tourism has a very large impact on economic activity and is usually seen as profitable. Many authors have tried to estimate profits from tourism and identify the conditions influencing increases in tourism expenditure (Crompton et al., 2001; Dwyer \& Forsyth, 1993; Fletcher, 1994). Tourism provides funds for local communities and has a significant economic multiplier effect. The role of innovation in developing tourism has been discussed by d'Hauteserre and Funck (2016, pp. 227-244). Many authors have analysed the factors influencing economic revenues from tourism. There are links between tourism development and economic indicators (Lim, 1999). Tourism expenditure and currency exchange rate have also been analysed to identify the impact of tourism on the economy (Coshall, 2000). Researchers have tried to apply the econometric model to explain the number of tourist arrivals (Vanegas \& Croes, 2000, pp. 946-963). Development pathways of small tropical islands have been analysed by Jędrusik (2014). Distance as a development factor on islands was analysed by Wites (2009). The impact of tourist arrivals on economic growth has also been confirmed by case studies done on islands (Podhorodecka, 2014, pp. 16-25). Tourism is an important factor in accelerating the GDP of islands, as confirmed by strategic documents relating to SIDS. Positive development paths for tourism on small island were presented by Scheyvens and Momsen (2008, pp. 491-510). However, the negative impact of tourism on the local economy is rarely analysed (Dwyer et al., 2004, p. 308). The development of agrotourism on islands has been discussed by Karampela et al. (2016, pp. 161-176). Grydehøj (2011) looked for economies of very small jurisdictions which, due to their small populations and small economies, react differently than large islands. Development on islands was described by Law et al. (2016) in the case of the Bali islands. Bianchi (2004) showed tourism initiatives on the Canary Islands. Capó et al. (2007) proved the reaction of a local economy to a rapid change in the export of natural resources on the Canary Islands. The relationship between tourism development and community for islands' economies was checked by Nunkoo et al. (2010) as well as by Kokkranikal et al. (2003), who studied the tourism development of the Lakshadweep Islands.

The global financial crisis has ended, but many sectors are still in recession. The tourism industry, however, is not experiencing a long-term recession (Reddyis, 2013). There has, in fact, been a decades-long increase in the tourism economy, with an average annual growth rate of 3 4\%. However, there have been exceptional crisis events, such as the Asian financial crisis of 1997, the Asian tsunami of 2004, and the terrorist attacks of September 2001 (Reddyis, 2013). This means that the rate of tourism growth has been weakened by economic crises, terrorist attacks, natural disasters (e.g. tsunami and earthquakes) and politics (e.g. restrictive visa regulations). Many authors have studied the impact of crisis events on tourism (Rucińska \& Lechowicz, 2014; Ryan, 1993). For example, Prideaux and Witt (2000) showed the impact of the Asian financial crisis on Australian tourism. There have also been studies on the impact of terrorist attacks (Blake \& Sinclair, 2003, p. 823; Goodrich, 2001; Pizam \& Fleischer, 2002), the impact of natural disasters (Kim et al., 2006, p. 931), and the impact of earthquakes (Wang, 2009, p. 76; Huang \& Min, 2002) on tourism. Crisis events on islands have been analysed by Shareef and McAleer (2005, pp. 313-314).

These crisis events result in a decrease in the tourist market, which is associated with a decrease in employment figures in the tourism economy and greater unemployment for the region, as well as a decrease in tourism business revenues. There are cuts to investment plans as costs rise. Moreover, crisis events make working and living conditions very stressful for local people. However, crisis events can sometimes provide positive outcomes, such as new ideas, new products, new markets, or new management programmes (Okumus \& Karamustafa, 2005, pp. 943-944). Enterprises have an increased opportunity to develop new strategies and bring in innovative products and processes, which results in lower prices (Zdon-Korzeniowska \& Rachwał, 2011). Tourists love peaceful conditions and not crisis events, so destinations need safe conditions for their visitors (Winiarski \& Zdebski, 2008). It is possible to differentiate ecological, 
regional, and global crises, but, although their origins are different, they are all connected in some way. For example, ecological crises, terrorist attacks, and wars may result in political crises that influence the tourism industry of a particular country. For instance, the war in the former Yugoslavia (in the beginning of the 1990s), conflicts in the Middle East, the war in Iraq (2003), the conflict in the Persian Gulf (1991), or political problems in Tibet (Okumus \& Karamustafa, 2005, pp. 943-944).

It is to be expected that the tourism sector, as a part of the global economy, is at risk from crises, and it needs to learn how to react to such events (Kotler \& Caslione, 2009; ZdonKorzeniowska \& Rachwał, 2011). There are different definitions of 'crisis', especially in political science, economics, and other social sciences (Dziedzic, 2012, p. 11). Broadly, however, a crisis is an unplanned and unexpected event that comes from inside or outside the environment or organisation. Crisis events are also characterised by their causing physical or mental fear and by being impossible to cope with by means of normal management procedures. For the purposes of this paper, the definition of financial crisis is a situation in which there is a shift in tendency from expansion to depression (Bremond et al., 2005, p. 87).

The effects of the global financial crisis on tourism were visible in the statistical data. In 2009, according to United Nations World Tourism Organization (UNWTO) data, the tourism industry recorded an $8 \%$ decrease compared to 2008. The regions most affected were Europe and the Middle East (Geise, 2009, pp. 42-45). In 2009 there was a decrease in foreign tourist arrivals of 4.3\% (from 920 to 880 million) (Dziedzic et al., 2010, pp. 13-14; World Tourism Organization, 2010, p. 5). Airlines reacted quickly to the global financial crisis (Geise, 2009, pp. 42-45).

The problem for all destinations was the European tourist market, which was responsible for almost 70\% of the worldwide decrease (World Tourism Organization, 2010, p. 5). The large impact of the European economic slump on other countries was due to European citizens being very active in tourism movement. In 2009, global earnings from tourism were 8\% lower than in 2008 (Dziedzic et al., 2010, pp. 13-14; World Tourism Organization, 2010, p. 5). Aviation sector earnings were also weaker due to falling passenger numbers (Dziedzic et al., 2010, pp. 1314; Air Passenger Market Analysis, 2017).

\section{An analysis of island reactions to the global financial crisis}

Comparing the data from 2011 and 2008, it is possible to identify territories with different results for three indicators, namely: tourism movement, employment in tourism, and level of tourist expenditure. Some territories coped much better with the impact that the global financial crisis had on tourism. Tourism movement was best for the Seychelles, Bahamas, Maldives, and Saint Kitts and Nevis. The poorest results regarding tourist arrivals were for Antigua and Barbuda, Anguilla, Dominica, the British Virgin Islands, and Saint Vincent and the Grenadines. With regard to the tourism employment market, Anguilla, Dominica, and Malta coped best. In terms of changes in tourism expenditure, Dominica, the Maldives, and Malta dealt with the crisis best.

The economy of the Caribbean region is highly dependent on tourism; especially in particular island territories such as the Bahamas, Anguilla, Barbados, Jamaica, and Saint Lucia (Lewis et al., 2009, p. 10). The main markets from which tourists arrive to this area are the United States, the United Kingdom, and Canada. The global financial crisis reduced demand in these markets and, even in the peak season, use of accommodation was less than in the same period in the year preceding the crisis. In the first quarter of 2009, countries such as the Bahamas, Antigua and Barbuda, Anguilla, and Saint Vincent and the Grenadines registered a double-digit decrease in the number of tourists visiting the selected islands compared to the same period in 2008 (Lewis et al., 2009, p. 10). 
Selecting conditions that potentially impact reaction to the global financial crisis

The research took into account independent island countries and dependent island territories in which tourist expenditure generates more than 10\% of GDP and for which there were appropriate data available from the World Travel \& Tourism Council (WTTC) and the United Nations World Tourism Organization (UNWTO) database. The 10\%-of-GDP criteria was applied because the author's previous research (Podhorodecka, 2008) on a larger group of islands showed that this specific situation and response was recorded in the group of countries which 'rely on tourism'.

The island territories which were excluded due to tourist expenses constituting less than $10 \%$ of GDP were Bahrain (7.6\% in 2008 and $8.3 \%$ in 2009), Comoros (7.5\% in 2008 and 5.9\% in 2009), Haiti (4.4\% in 2008 and $4.9 \%$ in 2009), Madagascar (7.2\% in 2008, 6.1\% in 2009), Reunion (2.1\% in 2008, 2.1\% in 2009), Taiwan (1.9\% in 2008, $1.8 \%$ in 2009$)$, East Timor $(0.3 \%$ in 2008 and $0.5 \%$ in 2009), Tonga (6.3\% in 2008 and $4.9 \%$ in 2009), and Trinidad and Tobago (2.0\% in 2008 and 2.9\% in 2009). The same situation (less than $10 \%$ of GDP) pertained for the Solomon Islands.

Hong Kong and Macau were excluded despite their share of tourist expenses being higher than 10\%: Hong Kong (9.2\% in 2008, 9.5\% in 2009 and 11.9\% in 2010) and Macau (83\% in 2008 and 86.6\% in 2009). Hong Kong and Macau are special Administrative Regions of the People's Republic of China and have a specific political and economical situation which is very different from the analysed island territories. In addition, despite having constituent islands, Hong Kong and Macau are connected with the mainland.

The analysis did not cover islands which strictly rely on tourism but which are part of a larger country (for example, the Canary Islands, which are a part of Spain; the Bali Islands, which are a part of Indonesia; and the Phuket islands, which are a part of Thailand). There was a problem with getting exact data on the tourism employment and tourism expenditures on such islands, which are an administrative part of a larger country.

In the case of Guam, which has a large tourism movement, there were no data on tourism employment or tourism expenditures. There were no data on tourism expenditures from the UNWTO database in the cases of American Samoa, French Polynesia, Nauru, Saint Eustatius, Saint Marten, Samoa, Sao Tome and Principe, Tuvalu, US Virgin Islands, Cabo Verde, Cayman Islands, Curaçao, Dominican Republic, Guadeloupe, Marshall Islands, Vanuatu, and Bonaire. No relevant data were also available for Åland Islands and Saint Helena (no statistical data in the UNWTO database). Belize, Guiana, Guinea-Bissau, and Suriname are not strictly islands, so they were not taken into account. Papua New Guinea was too big $\left(462,840 \mathrm{~km}^{2}\right)$ to take into account. Moreover, there was no information about inbound tourism expenditure over GDP in the UNWTO database.

Island areas were divided into particular types according to the reaction of their tourism sector to the global financial crisis. The division into four types was made based on the scale of changes in incoming tourism during the global financial crisis, as follows (see also Table 1):

A - no (or very low) decrease in tourism movement during the global financial crisis (4territories),

B - a small, short-term decrease, but a better situation in 2011 than before the crisis(4 territories),

C - a similar situation in 2011 to before the crisis (4 territories) - only reaching precrisislevels after four years' recovery, and

D - a long-term recession and a worse situation in 2011 than in 2008 (5 territories). 
Table 1: Ranking island economic resilience to the global financial crisis, based on changes in tourist movement (2011 and 2008).

\begin{tabular}{|l|l|l|l|}
\hline & Island territory & $\begin{array}{l}\text { Changes in tourist } \\
\text { movement }(2011 / 2008)\end{array}$ & Type \\
\hline 1 & Maldives & $136 \%$ & A \\
\hline 2 & Saint Kitts and Nevis & $134 \%$ & A \\
\hline 3 & The Bahamas & $127 \%$ & A \\
\hline 4 & Seychelles & $121 \%$ & A \\
\hline 5 & Jamaica & $108 \%$ & B \\
\hline 6 & Malta & $107 \%$ & B \\
\hline 7 & Aruba & $106 \%$ & B \\
\hline 8 & Saint Lucia & $103 \%$ & B \\
\hline 9 & Barbados & $102 \%$ & C \\
\hline 10 & Mauritius & $101 \%$ & C \\
\hline 11 & Grenada & $100 \%$ & C \\
\hline 12 & Cyprus & $100 \%$ & C \\
\hline 13 & Antigua and Barbuda & $98 \%$ & D \\
\hline 14 & Anguilla & $97 \%$ & D \\
\hline 15 & Dominica & $89 \%$ & D \\
\hline 16 & $\begin{array}{l}\text { British Virgin Islands } \\
\text { Dziewicze }\end{array}$ & $89 \%$ & D \\
\hline 17 & $\begin{array}{l}\text { St Vincent and the } \\
\text { Grenadines }\end{array}$ & $83 \%$ & \\
\hline
\end{tabular}

Source: own elaboration.

According to Kaczmarska (2014, pp. 201-203) the factors impacting tourism are diverse but can be divided into five main groups: social, economic, political, technical, and environmental. Economic factors are considered the most important. They include an increase in income, uniformity of income distribution, and a stable financial situation with beneficial economic conditions. Among the political factors, the author lists foreign policy, while among the technical factors, she lists transport infrastructure, i.e. availability of transport.

The present article analyses the factors behind various levels of resilience to the global financial crisis in island tourism economies. Specifically, the following factors were assessed for their statistical correlation to the aforementioned levels (A-D) of resilience:

1. length of time as an independent state or dependent territory,

2. degree of dependence on the tourism sector (the relationship between income fromtourism and GDP),

3. diversification of markets for incoming tourism (the degree of diversification in themix of markets from which incoming tourists originate),

4. dominance of the main incoming market,

5. level of dependence on European markets, 
6. level of dependence on North American and South American markets,

7. duration of flights to and from the main market,

8. level of economic development,

9. quality of life of residents (measured by HDI index),

10. tourism expenditure per tourist, and

11. changes in governmental expenditure on tourism.

All factors were chosen due to data accessibility and relevance of factors. The most important factors are considered to be economic and political, so were accompanied by a bigger number of indicators. Regarding length of time as an independent state, in the beginning such a country may have advantages in tourist origin markets and foreign investments but, after several decades, an earlier dependence brings disadvantages, such as 'tourism leakage', i.e. profits from tourism in less developed countries being exported to the developed countries of the facility owners. The above factors can be classified as: political (1, 3, 4, and 11), economic $(2,10,5,6$, 8, and 10), technical (7), and social (9).

The following hypotheses were proposed:

1. The longer the state had been independent, the better the reaction to the global financial crisis. Independent policy provides the possibility to better control foreign investment and taxation in the tourism sector.

2. The degree to which an island area was dependent on tourism influenced the island area's reaction to the global financial crisis (i.e. the relationship between income from tourism and GDP). This is because countries which depend heavily on tourism should react very quickly, because they have a lot of income to lose. They should provide money for tourism promotion campaigns and on showing a competitive tourism product.

3. The level of dependence of an island area on a few main markets for incoming tourism, (i.e.the more diverse the mix of incoming markets, the better the tourism sector's situation during the global financial crisis). If the crisis hits the main market of an island, it is better to have the possibility to provide tourists from other important markets.

4. The level of dependence on the main market influenced reaction to the global financial crisis; the lower, the better for the island area. A high level of dependence on one main market may bring disadvantages, especially when this first main market is hit by the global economic crisis.

5. The level of dependence on European markets influenced reaction to the global financial crisis of a given island area; the lower, the better. The global economic crisis also hit European countries, so islands which did not heavily rely on European markets could cope with the crisis in tourism better. Moreover, there was unusually large European-sourced tourism during the crisis. 6. The level of dependence of island areas on the markets of North America and South America influenced reaction to the global financial crisis; the higher, the worse for the island area (because the crisis affected the American market first). The global economic crisis first hit American countries, so islands which were not heavily reliant on American markets could also cope with the crisis in tourism better.

7. The duration of flights to and from the main market (expressed in hours) influenced reaction to the global economic market; the shorter, the better-because of the cost to tourists and ease of travel. 8. The tourist expenditure per tourist visiting a given island area influenced reaction to the global financial crisis; the higher, the better. This can be explained by exclusive and expensive destinations being able to reduce prices and attract more tourists-'best value for the best price'. 9. The economic development of a given island area influenced reaction to the global financial crisis. A more developed country or dependent territory has funds and tools to cope with crisis events in the economy and in the tourism sector. 
10. The quality of life on a given island area influenced reaction to the global financial crisis (HDI index). A wealthier and well-developed country or dependent territory has funds to cope with crisis events in the tourism sector.

11. Changes in governmental expenditure on tourism influenced reaction to the global financial crisis; the greater the expenditure, the better. Increasing governmental expenditure on tourism could provide better results during a crisis in the tourism sector.

\section{Statistical analysis of the conditions relating to reaction to the global financial crisis}

Verification of the purposes and hypotheses presented above was conducted in the sequence presented. Data from secondary sources came from UNWTO and the World Travel \& Tourism Council (WTTC).

1. Length of time as an independent state (or whether it is still a dependent area)

Analysing status, and the year of the selected island territory's independence, shows that most dependent areas belong to type D (the worst reaction to the global financial crisis). Conversely, all type A island areas are independent countries, as are nearly all type B territories. Below is a list of the countries, of which 1 to 14 have gained independence (date of independence in brackets) and 15 to 17 are dependent territories. Their classification into type of economic reaction of the tourism sector to the global financial crisis is also indicated.

$\begin{array}{ll}\text { 1. Cyprus (1960) } & \text { C } \\ \text { 2. Jamaica (1962) } & \text { B } \\ \text { 3. Malta (1964) } & \text { B } \\ \text { 4. Maldives (1965) } & \text { A } \\ \text { 5. Barbados (1966) } & \text { C } \\ \text { 6. Mauritius (1968) } & \text { C } \\ \text { 7. The Bahamas (1973) } & \text { A } \\ \text { 8. Grenada (1974) } & \text { C } \\ \text { 9. Seychelles (1976) } & \text { A } \\ \text { 10. Dominica (1978) } & \text { D } \\ \text { 11. Saint Lucia (1979) } & \text { B }\end{array}$

12. Saint Vincent and the Grenadines (1979) D

13. Antigua and Barbuda (1981) D

14. Saint Kitts and Nevis (1983) A

15. Anguilla - dependent territory of UK D

16. Aruba - dependent territory of Netherlands B

17. British Virgin Islands - British Overseas Territory D

Table 1 ranks the resilience of tourism economies to the global financial crisis, based on the change in tourism movement between 2008 and 2011. The higher ranks the better reaction of island territory in terms of changes in tourist movement due to the global economic crisis.

In the study the Spearman correlation ratio was used, as it is the appropriate method for the calculation of correlations of small samples (a sample of at least 15). Pearson correlation ratio needs a sample of at least 30 islands. Moreover, the Spearman correlation method is appropriate even if data are limited. This is why it is the method used with low quality data, especially. Moreover, the Pearson correlation method needs a normal distribution of data. There is no such limitation on the Spearman correlation ratio. The Spearman rank correlation coefficient between length of time as an independent state and resilience of tourism to the global financial crisis for the 17 island territories $(n=17)$ was 0.378 . There is therefore a low correlation between the length of time as an independent state and a better reaction by the tourism sector to the global financial crisis. For further analysis, the Kendall rank correlation coefficient was used. Both the 
Spearman rank correlation coefficient and the Kendall rank correlation coefficient are measures of monotonic dependencies between random variables, but the two coefficients are interpreted in different ways. The Kendall rank correlation coefficient should be interpreted as a probability. The formula for the Spearman correlation ratio:

$$
r=1-\frac{6 \sum\left(V_{x}-V_{y}\right)^{2}}{N^{3}-N}
$$

Where: $\mathrm{N}$-number of analysed sample, $\mathrm{r}$ - Spearman correlation ratio, $\mathrm{Vx}$ - value of variable $\mathrm{X}$, $\mathrm{Vy}$-value of variable $\mathrm{Y}$.

The formula for the Kendall rank correlation coefficient for a sample (Abdi, 2007, pp. 5-7):

$$
r=\frac{P-Q}{P+Q+T}
$$

Where $r$ is the value of the Kendall rank correlation coefficient for a sample, $P$ is the number of compatible pairs (i.e. changing in the same direction), and $Q$ is the number of non-compatible pairs (i.e. changing in a different direction).

The Kendall rank correlation coefficient was calculated between reaction to the global financial crisis regarding tourism and the length of time as an independent state. This dependence for the 17 island areas (i.e. $\mathrm{n}=17$ ) was 0.279 . Therefore, again, there is a low correlation between length of time as an independent state and the tourism sector reacting better to the global financial crisis.

2. Degree of dependence of an island area on tourism (the relationship between income from tourism and GDP) It would be fair to assume that the tourism sector of island areas that were heavily dependent on tourism coped poorly with the global financial crisis, while areas less dependent on tourism should have coped better; economic diversification should be a factor in better performance during the global financial crisis. Table 2 shows tourism income as a percentage of GDP and the resilience of island areas to the global financial crisis. It was analysed whether the degree of reaction to the global financial crisis in terms of tourist numbers for particular island areas depends on the share of tourism as a percentage of GDP. 
Table 2: The relation of tourism income to GDP (in \%) and reaction of the tourism sector to the global financial crisis.

\begin{tabular}{|c|c|c|c|}
\hline & Island territory & $\begin{array}{l}\text { Share of income } \\
\text { from tourism as } \\
\text { part of GDP }(\%)^{\star}\end{array}$ & $\begin{array}{l}\text { Rank of island } \\
\text { reaction to } \\
\text { crisis }\end{array}$ \\
\hline 1 & Anguilla & 40.3 & 14 \\
\hline 2 & Antigua and Barbuda & 27.7 & 13 \\
\hline 3 & Aruba & 52.6 & 7 \\
\hline 4 & Barbados & 25.3 & 9 \\
\hline 5 & British Virgin Islands & n.d. & 16 \\
\hline 6 & Cyprus & 11.6 & 12 \\
\hline 7 & Dominica & 22.9 & 15 \\
\hline 8 & Grenada & 13.9 & 11 \\
\hline 9 & Jamaica & 14.4 & 5 \\
\hline 10 & Maldives & 97.9 & 1 \\
\hline 11 & Malta & 16.4 & 6 \\
\hline 12 & Mauritius & 15.8 & 10 \\
\hline 13 & Saint Kitts and Nevis & 12.6 & 2 \\
\hline 14 & Saint Lucia & 28.2 & 8 \\
\hline 15 & $\begin{array}{l}\text { St. Vincent and the } \\
\text { Grenadines }\end{array}$ & 13.1 & 17 \\
\hline 16 & Seychelles & 39.5 & 4 \\
\hline 17 & The Bahamas & 29.3 & 3 \\
\hline
\end{tabular}

n.d. - no data. ${ }^{\star}$ Reference Year 2012 - the end of the global financial crisis. Source: own elaboration based on World Tourism Organization (2017) data.

Spearman's rank correlation coefficient between the share of tourism in GDP and resilience to the crisis for $n=16$ (no data for the British Virgin Islands) was 0.405 . This indicates a moderate positive correlation. The Kendall rank correlation coefficient for the dependence calculated for 16 island areas $(n=16)$ was 0.233 , which can be interpreted as a low correlation between the share of tourism in GDP and tourism sector resilience to the global financial crisis. This means, unexpectedly, that countries with a higher share of tourism in GDP, and therefore greater dependence on tourism, coped better with the global financial crisis.

It is possible that these island areas did not underestimate the situation and, knowing that they would have a lot to lose, were prepared to react quickly and appropriately to the global financial crisis; therefore, the higher the share of tourism in GDP, the better the ranking of resilience to the crisis. This hypothesis is supported by examples such as that of the Maldives, which had a very high share of tourism in GDP (i.e. 97.7\%) and the best reaction to the global financial crisis (first position in the ranking). Another example confirming this dependence is the Seychelles, whose share of tourism as part of GDP was 39.5\% and was fourth in the ranking. The Seychelles provided money for a special tourism campaign-the "Affordable Seychelles 
Marketing Campaign" and "Market Source Over Satisfaction Supported by Air Access" during the global economic crisis. The Ministry of Tourism of Seychelles also provided more funds for tourism promotion during the global economic crisis (in 2009-30 mln rupees, in 2010-35 mln rupees, in $2011-38 \mathrm{mln}$ rupees).

\section{Level of diversification of markets for incoming tourism}

The diversification of markets for incoming tourism was assessed using a modified diversification coefficient of Amemiya's economic base. This ratio is usually used in economic geography to measure degree of diversification in employment. It is used to analyse particular branches of the economy and to analyse employment in terms of major employers in a given municipality or region. It is therefore possible to calculate the diversification coefficient for the number of people working in particular branches or sectors. Diversification can be analysed at the micro scale, i.e. at the scale of individual enterprises. Thanks to this coefficient it is possible to indicate areas that are excessively dependent on one sector or one market, or in relation to one employer (Gwosdz et al., 2010; Jerczyński, 1973).

The coefficient is so universal that it has been used in this article to analyse the diversification of foreign markets. This approach is innovative, as this coefficient has never been used before to analyse tourist movement. The analysis was performed using the number of foreign tourists arriving from each of the main markets at the beginning of the global financial crisis. The number of markets taken into account was dictated by data availability. For many countries, the analysis was performed for the 20 main incoming tourism markets (usually these markets constituted $90-95 \%$ of tourism entering a given territory).

The diversification coefficient ranges from 0 to 1 (i.e. $<0.1>$ ). A value of 0 means a completely diversified structure, while 1 means the complete dominance of one branch or entity, or dependence on one market (Gwosdz et al., 2010, p. 137). For better readability of the coefficient, it was multiplied by 100 . For the initial interpretation of the coefficient, the division suggested by Kubejko-Polańska was used and, therefore, the coefficient values (after multiplying by 100) were grouped as follows: below 15 means high diversification; from 15 to 30, average diversification; from 30 to 60 , low diversification; and 60 and above, very low. Below is the formula that was used in the further analysis (Jerczyński, 1973, pp. 74-83). The formula was modified appropriately for the analysis of the coefficient of incoming tourism diversification. Formula for the coefficient of diversification for incoming tourism:

\section{Coefficient of diversification}

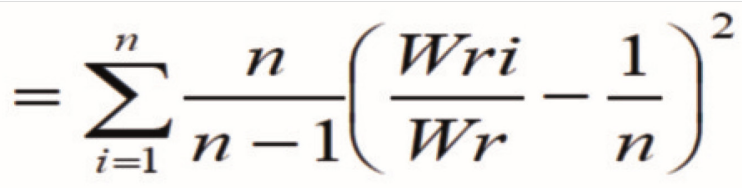

Where $n$ is the number of identified markets, $W r i$ is the size of a given market, and $W r$ is the size of the entire market.

It should be remembered that a large share of tourism from one market for a given island area causes excessive dependence on the social, economic, and political situation of that country. If a given market of incoming tourism experiences recession or another type of crisis, and it is the most important market, it may cause the tourism economy of a given destination (in the case of this article, an island area) to collapse. 
Table 3: Changes in tourism movement, differentiation ratio, main market, level of dependence on European and American markets (\% value).

\begin{tabular}{|c|c|c|c|c|c|}
\hline & Island territory & $\begin{array}{l}\text { Changes in } \\
\text { tourist } \\
\text { movement } \\
(2011 / 2008)\end{array}$ & $\begin{array}{l}\text { Differentiat } \\
\text { ion of } \\
\text { markets ratio }\end{array}$ & $\begin{array}{l}\text { Main } \\
\text { market } \\
(\%)\end{array}$ & Main market \\
\hline 1 & Maldives & $136 \%$ & 5.5 & 16.2 & UK \\
\hline 2 & Saint Kitts and Nevis` & $134 \%$ & n.d. & 58.4 & USA \\
\hline 3 & The Bahamas & $127 \%$ & 69.0 & 80.1 & USA \\
\hline 4 & Seychelles & $121 \%$ & 7.1 & 19.9 & France \\
\hline 5 & Jamaica & $108 \%$ & 46.6 & 64 & USA \\
\hline 6 & Malta & $107 \%$ & 11.8 & 31 & UK \\
\hline 7 & Aruba & $106 \%$ & 42.7 & 64.9 & USA \\
\hline 8 & Saint Lucia & $103 \%$ & 21.3 & 42.2 & USA \\
\hline 9 & Barbados & $102 \%$ & 49.1 & 33.8 & UK \\
\hline 10 & Mauritius & $101 \%$ & 13 & 32.3 & France \\
\hline 11 & Grenada & $100 \%$ & 25 & 22.5 & USA \\
\hline 12 & Cyprus & $100 \%$ & 22 & 50.0 & UK \\
\hline 13 & Antigua and Barbuda & $98 \%$ & 25.4 & 35.0 & USA \\
\hline 14 & Anguilla & $97 \%$ & 38.9 & 62.7 & USA \\
\hline 15 & Dominica & $89 \%$ & 8.8 & 25.1 & USA \\
\hline 16 & Brit. V. Islands & $89 \%$ & 51.3 & 47.3 & USA \\
\hline 17 & St Vincent and the Gren. & $83 \%$ & 10.3 & 26.7 & USA \\
\hline
\end{tabular}

n. d. - no data.

*In the case of Saint Kitts and Nevis the differentiation ratio was not calculated because of UNWTO official statistics existing for only 3 markets. Source: own elaboration.

Spearman's rank correlation coefficient was calculated for the diversification coefficient and ranking of resilience to the crisis for the selected island territories. The correlation for 16 island areas $(\mathrm{n}=16)$ (no data for Saint Kitts and Nevis) was 0.056, while the Kendall rank correlation coefficient for the same group was 0.067 . This indicates a lack of correlation between the analysed features, and the hypothesis must therefore be considered unconfirmed. No dependence was indicated between level of diversification of foreign incoming tourism markets and the resilience of island areas' tourism sectors to the global financial crisis.

\section{Extent of dominance of the main market of foreign tourism}

An analysis of the data presented in Table 3 was performed. For 11 island territories, the dominant market for incoming tourism was the United States, for three territories it was the 
United Kingdom, and for two it was France. The Spearman rank correlation coefficient between the size of a given island territory's dominant market and its reaction to the global financial crisis was 0.096 for the 16 island areas $(n=16)$; while the Kendall rank correlation coefficient for the same set of data was 0.059. Therefore, no dependence was observed between size of dominant market and reaction to the global financial crisis. Accordingly, the hypothesis posed at the beginning was not confirmed.

\section{Island area's level of dependence on European markets}

In this study, it was assumed that the global financial crisis reached Europe later than it did the United States. Moreover, Europe was not affected by the global financial crisis to the same degree as was the United States. According to World Bank statistics, the GDP growth rate in 2008 in United States was $-0.3 \%$, and $-2.8 \%$ in 2009. European Union growth rate in 2008 was $+0.5 \%$, and $-4.4 \%$ in 2009 . Numerous countries in Europe did not register any decrease in GDP and turned out to be what have been referred to as 'green islands' (e.g. Poland's GDP growth rate in 2008 was $+4.2 \%$, and $+2.8 \%$ in 2009). Later in this article, calculations of the Spearman rank correlation coefficient are made between the share of European markets and better reaction to the global financial crisis. This dependence was measured by the Spearman rank correlation coefficient for $n=17$ and was 0.137 , while the Kendall rank correlation coefficient for the same set of data was 0.103 . This indicates a lack of relationship between the dependence of the tourism economy on European markets and a better reaction of the tourism economy to the global financial crisis. The level of dependence of particular island territories on European tourism is presented in Table 4.

Table 4: Dependence on European and American markets of island territories (\% value).

\begin{tabular}{|l|l|c|c|}
\hline \multicolumn{1}{|c|}{ Island territory } & $\begin{array}{c}\text { Dependence on } \\
\text { European markets }\end{array}$ & $\begin{array}{c}\text { Dependence on } \\
\text { American markets* }\end{array}$ \\
\hline 1 & Anguilla & $13 \%$ & $83 \%$ \\
\hline 2 & Antigua and Barbuda & $41 \%$ & $57 \%$ \\
\hline 3 & Aruba & $9 \%$ & $90 \%$ \\
\hline 4 & Barbados & $44 \%$ & $54 \%$ \\
\hline 6 & British Virgin Islands & $86 \%$ & $12 \%$ \\
\hline 7 & Cyprus & $96 \%$ & $1 \%$ \\
\hline 8 & Dominica & $17 \%$ & $82 \%$ \\
\hline 9 & Grenada & $34 \%$ & $50 \%$ \\
\hline 10 & Mamaica & $16 \%$ & $83 \%$ \\
\hline 11 & Maldives & $72 \%$ & $1 \%$ \\
\hline 12 & Mauritius & $93 \%$ & $65 \%$ \\
\hline 13 & Saint Kitts and Nevis & $2 \%$ & $88 \%$ \\
\hline 14 & Saint Lucia & $8 \%$ & $67 \%$ \\
\hline 15 & Saint Vincent and the Grenadines & $31 \%$ & $73 \%$ \\
\hline 16 & Sevchelles & $26 \%$ & $3 \%$ \\
\hline 17 & The Bahamas & $79 \%$ & $91 \%$ \\
\hline
\end{tabular}

* North and South America. Source: own elaboration.

\section{Island area's level of dependence on American markets}

Spearman's rank correlation coefficient between the share of the markets of North America and South America and a better reaction to the crisis was calculated. The largest shares of North American and South American markets were for Aruba (90\%), Saint Kitts and Nevis (88\%), and Anguilla (83\%). The smallest were for Malta (1\%), the Maldives (2\%), and the Seychelles (3\%). This dependence, measured using the Spearman rank correlation coefficient for 17 island areas $(n=17)$, was -0.077 . The Kendall rank correlation coefficient for the same set of data was 0.074. This means that no dependence was observed between a high share of North American and South American markets for incoming tourism and reaction of the tourism economy to the global financial crisis. 


\section{Duration of flights from/to the main markets, in hours}

It was hypothesised in this study that transport communication availability should positively affect the reaction of the tourism sector to the global financial crisis. The tourism industry on tropical islands is dependent on flights. The taxation of tourist services should take into account islands' dependence on air transport. A large number of flights means competitive prices, and therefore impacts the attractiveness of the entire tourism offer for a given island. Table 5 shows flight duration from main market (in hours) and the reaction of the selected island territories' tourism sectors to the global financial crisis. The Spearman rank correlation coefficient was calculated for flight duration from an island territory's main market and reaction to the global financial crisis. The Kendall rank correlation coefficient was 0.140 , while the dependence measured by the Spearman rank correlation coefficient for the 17 island areas $(n=17)$ was 0.017 . This means that there is no observable dependence between flight duration in hours from the main market from which tourists arrive and the tourism economy's reaction to the global financial crisis for the selected island territories.

Table 5: Length of aircraft connections in hours and reaction of tourist islands to global financial crisis.

\begin{tabular}{|c|c|c|c|}
\hline & Island territory & Main & Length of aircraft connections (in hours) \\
\hline 1 & Maldives & UK & 12 hours, $35 \min$ ( 1 change) London - Male \\
\hline 2 & Saint Kitts and Nevis & USA & 7 hours, 40 min (1 change) New York - SKB \\
\hline 3 & The Bahamas & USA & 3 hours, 15 min (direct) New York - Nassau \\
\hline 4 & Seychelles & France & 13 hours, 10 min ( 1 change) Paris - Victoria \\
\hline 5 & Jamaica & USA & 6 hours, 21 min (1 change) New York - Kingston \\
\hline 6 & Malta & UK & 3 hours, 10 min (direct) London - Luqa \\
\hline 7 & Aruba & USA & 4 hours, $45 \mathrm{~min}$ (direct) New York - Oranjestad \\
\hline 8 & Saint Lucia & USA & 7 hours, 20 min (1 change) New York - Castries \\
\hline 9 & Barbados & UK & 8 hours, $10 \mathrm{~min}$ (direct) London - Bridgetown \\
\hline 10 & Mauritius & France & 11 hours, $40 \mathrm{~min}$ (direct) Paris - Port Louis \\
\hline 11 & Grenada & USA & $\begin{array}{l}8 \text { hours, } 16 \text { min (1 change) New York - Saint } \\
\text { George's }\end{array}$ \\
\hline 12 & Cyprus & UK & 4 hours, $30 \mathrm{~min}$ (direct) London - Larnaka \\
\hline 13 & Antigua and Barbuda & USA & 8 hours, 15 min (1 change) New York - Saint John's \\
\hline 14 & Anguilla & USA & $\begin{array}{l}9 \text { hours, } 23 \text { min ( } 2 \text { changes) New York - The } \\
\text { Valley }\end{array}$ \\
\hline 15 & Dominica & USA & 7 hours, 45 min ( 1 change) New York - Margiot \\
\hline 16 & British Virgin Islands & USA & 8 hours, 13 min ( 1 change) New York - Road Town \\
\hline 17 & Saint Vincent and the Gren. & USA & 8 hours, 40 min (1 change) New York - Kingstown \\
\hline
\end{tabular}

Source: Own elaboration based on information from www.esky.pl.

\section{Tourism expenditure per foreign tourist}

It was hypothesised in this study that areas of highest tourism expenditure coped better with the global financial crisis. It might also be assumed that areas that earned the most from tourism had to be more committed to preventing the consequences of the global financial crisis from affecting the tourism sector. The table below presents islands ranked by resilience to the crisis based on the change in the number of tourist for 2011 and 2008, and average tourism expenditure per tourist. 
Table 6: Ranking of island tourism economy resilience to the crisis and average expenditures per tourist, GPD per citizen according to PPP, human development index, changes in employment in tourism, and changes in tourist expenditure (2011 and 2008).

\begin{tabular}{|l|l|c|c|c|c|c|}
\hline & $\begin{array}{l}\text { Chosen island } \\
\text { territory }\end{array}$ & $\begin{array}{l}\text { Average tourist } \\
\text { expenditure } \\
\text { per tourist* } \\
\text { (in USD) }\end{array}$ & $\begin{array}{l}\text { Gross } \\
\text { Domestic } \\
\text { Product per } \\
\text { capita (PPP) }\end{array}$ & HDI & $\begin{array}{l}\text { Changes in } \\
\text { employment } \\
\text { in tourism } \\
(\mathbf{2 0 1 1} / \mathbf{2 0 0 8})\end{array}$ & $\begin{array}{l}\text { Changes in } \\
\text { tourist } \\
\text { expenditure } \\
(\mathbf{2 0 1 1} / \mathbf{2 0 0 8})\end{array}$ \\
\hline 1 & Maldives & 2,245 & $6,665.8$ & 0.698 & $-4.00 \%$ & $19.8 \%$ \\
\hline 2 & Saint Kitts and Nevis & 151 & $14,132.8$ & 0.750 & $-6.30 \%$ & $-6.7 \%$ \\
\hline 3 & The Bahamas & 436 & $22,312.1$ & 0.789 & $-2.00 \%$ & $0.1 \%$ \\
\hline 4 & Seychelles & 1,961 & $16,185.9$ & 0.756 & $-2.20 \%$ & $-4.2 \%$ \\
\hline 5 & Jamaica & 752 & $5,290.5$ & 0.715 & $-10.00 \%$ & $-9.4 \%$ \\
\hline 6 & Malta & 695 & $22,775.0$ & 0.829 & $8.90 \%$ & $10.0 \%$ \\
\hline 7 & Aruba & 862 & $25,354.8$ & 0.975 & $8.30 \%$ & $0.5 \%$ \\
\hline 8 & Saint Lucia & 301 & $7,328.4$ & 0.714 & $0.00 \%$ & $3.2 \%$ \\
\hline 9 & Barbados & 972 & $14,917.1$ & 0.776 & $-22.50 \%$ & $-17.4 \%$ \\
\hline 10 & Mauritius & 1258 & $9,477.8$ & 0.771 & $-5.70 \%$ & $-0.8 \%$ \\
\hline 11 & Grenada & 243 & $13,900.0$ & 0.770 & $3.70 \%$ & $-11.8 \%$ \\
\hline 12 & Cyprus & 1,043 & $25,249.0$ & 0.845 & $-10.40 \%$ & $-19.7 \%$ \\
\hline 13 & Antigua and Barbuda & 323 & $13,342.1$ & 0.760 & $0.90 \%$ & $-6.6 \%$ \\
\hline 14 & Anguilla & 143 & $12,200.0$ & 0.865 & $40.00 \%$ & $2.8 \%$ \\
\hline 15 & Dominica & 127 & $7,175.6$ & 0.717 & $26.90 \%$ & $39.5 \%$ \\
\hline 16 & British Virgin Islands & 436 & $42,300.0$ & 0.945 & $-15.70 \%$ & $-13.0 \%$ \\
\hline 17 & $\begin{array}{l}\text { St Vincent and the } \\
\text { Grenadines }\end{array}$ & 325 & $6,485.7$ & 0.719 & $-5.60 \%$ & $-6.4 \%$ \\
\hline
\end{tabular}

$\star$ data for $2009, \star \star$ Including one-day visitors. Sources: Own elaboration based on: United Nations Development Programme (2016), World Tourism Organization (2017), World Bank (2017), IndexMundi (2017).

The dependence between the ranking of resilience to the crisis and average tourism expenditure per tourist was studied. The Kendall rank correlation coefficient for the two studied features was 0.273 . This can be interpreted as a low positive dependence between the average expenditure per tourist and reaction of island territories to the global crisis, while the Spearman rank correlation coefficient was 0.418 , indicating a moderate, negative dependence. One example of this dependence is that of the Maldives, whose tourism industry had a very good outcome despite the global financial crisis. The Maldives were first in the ranking of reactions to the global financial crisis in terms of changes in tourism, and tourism expenditure per tourist was US $\$ 2,245$. The Seychelles, where expenditure per tourist was US $\$ 1,961$, was fourth in the ranking. Therefore, the hypothesis posed at the beginning of the chapter regarding the dependence between tourism expenditure and resilience of island areas to the crisis can be considered confirmed. Moreover, we can also presume that exclusive destinations, characterised by very high prices, and therefore high tourism expenditure, were not affected by the global financial crisis to the same extent. In the literature, it has been argued that, during the crisis, the groups with the lowest salaries lost the most, and that the crisis did not affect the wealthiest in the same way (Walsh, 2015).

\section{Island areas' level of economic development}

It was also analysed whether the level of economic development affected the reaction of the tourism sector to the global financial crisis. The index of GDP value according to purchasing power parity per resident was used. Table 6 shows reaction of the tourism sector using changes in tourism after the global financial crisis, and the GDP value according to PPP per resident. It turns out that the Kendall rank correlation coefficient between GDP value by PPP per resident and changes in tourism during the global financial crisis was -0.044, and the Spearman rank correlation coefficient for the same was -0.049 . Accordingly, in both cases, no dependence was recorded between level of economic development and reaction to the crisis of selected island areas. 
10. Quality of life on an island area

It was also analysed whether the quality of life for residents of a given island territory measured by HDI index influenced the various reactions of the tourism sector to the global financial crisis. The results were as follows: the Kendall rank correlation coefficient was -0.191 , which can be interpreted as no correlation; the Spearman rank correlation coefficient was -0.267 . This indicates a weak negative correlation. Summarising the results of the analysis, a weak negative dependence was observed between quality of life (by HDI index) on selected island territories and reaction of the tourism sector to the global financial crisis.

\section{Changes in governmental expenditure on tourism}

Analysis was made of the dependence between the island economies' resilience to the global financial crisis (in terms of changes in tourism) and changes in governmental expenditure on tourism. The Kendall rank correlation coefficient was -0.015 . The Spearman rank correlation coefficient between the analysed features was -0.053 . This indicates a lack of correlation between the analysed features.

Table 7: Government expenditure on tourism for 2009-2015 and change 2011/2009. Source: own elaboration based on: World Travel \& Tourism Council (2015).

\begin{tabular}{|c|c|c|c|c|c|c|c|c|c|}
\hline & Island territory & 2009 & 2010 & 2011 & 2012 & 2013 & 2014 & 2015 & $\begin{array}{l}2011 \\
/ 2009\end{array}$ \\
\hline 1 & guilla (XCD mln) & 16.7 & 16.7 & 14.8 & 14.6 & 14.6 & 14.9 & 15.4 & $11.4 \%$ \\
\hline 2 & Antigua and Barbuda (XCD & 170.5 & 144.3 & 138.2 & 142.8 & 149.8 & 158.8 & 164.3 & $-18.9 \%$ \\
\hline 3 & Aruba (AWG mln) & 170.8 & 177.7 & 171.4 & 184.6 & 195.2 & 199.3 & 204.7 & $0.4 \%$ \\
\hline 4 & Barbados (BBD mln) & 261.6 & 253.8 & 250.4 & 242.5 & 228.0 & 218.8 & 214.0 & $-4.3 \%$ \\
\hline 5 & tish Virgin Islands & 563.8 & 645.3 & 628.6 & 642.1 & 643.7 & 653.1 & 663.3 & $11.5 \%$ \\
\hline 6 & (EI & 282.7 & 285.4 & 288.1 & 272.6 & 256.1 & 247.0 & 248.5 & $1.9 \%$ \\
\hline 7 & & 31.4 & 33.3 & 33.6 & 38.6 & 38.1 & 40.0 & 42.1 & $7.0 \%$ \\
\hline 8 & & 36.0 & 37.1 & 36.8 & 37.3 & 40.2 & 39.4 & 40.0 & $2.2 \%$ \\
\hline 9 & $\mathrm{~J}$ & 38.1 & 36.7 & 36.7 & 37.9 & 36.6 & 37.1 & 37.7 & $-3.7 \%$ \\
\hline 10 & & $1,155.4$ & $1,069.7$ & $1,004.5$ & $1,054.5$ & $1,128.3$ & $1,182.9$ & .242 .5 & $-13.1 \%$ \\
\hline 11 & Malta (EUR 1 & 132.0 & 134.9 & 138.1 & 145.7 & 149.3 & 158.9 & 163.0 & $4.6 \%$ \\
\hline 12 & Mauritius (MUR mln) & 44.4 & 48.8 & 51.3 & 53.4 & 48.9 & 53.3 & 57.7 & $15.5 \%$ \\
\hline 13 & Saint Kitts and Nevis (X & 43.5 & 42.1 & 42.4 & 47.9 & 50.4 & 52.5 & 55.1 & $-2.5 \%$ \\
\hline 14 & Saint Lucia (XCD mln) & 29.6 & 30.1 & 30.0 & 31.0 & 31.5 & 31.4 & 32.0 & $1.4 \%$ \\
\hline 15 & $\begin{array}{l}\text { Saint Vincent and the } \\
\text { Grenadines (XCD mln) }\end{array}$ & 33.0 & 29.9 & 33.1 & 35.6 & 37.5 & 38.4 & 39.6 & $0.3 \%$ \\
\hline 16 & Seychelles (SC & 742.3 & 740.4 & 790.5 & 859.0 & 860.9 & 865.9 & 880.9 & $6.5 \%$ \\
\hline 17 & The $\mathrm{F}$ & 98.6 & 98.9 & 108.8 & 110.6 & 117.6 & 121.5 & 2 & \\
\hline
\end{tabular}

Analysis was also performed for changes in tourism employment and changes in tourism expenditures. The data used for the analysis below is presented in Appendix 1. To analyse employment in tourism, WTTC data were used, and to analyse expenditure, UNWTO data were used. Moreover, when analysing the Spearman correlation ratio and the stronger outcomes of correlation, linear regression analysis was done only for high or average outcomes of correlations (more than 0.4 ): 
1 - degree to which an island area is dependent on tourism and changes in tourist movement

$\mathrm{y}=0.332 \mathrm{x}+97.3$

$\mathrm{y}$-changes in tourist movement $\mathrm{x}$-degree of

island area dependency on tourism

Linear regression analysis statistically significant at level: 0.000 for A and 0.59 for B.

Fig. 1 Linear regression for island area dependency on tourism and changes in tourist movement

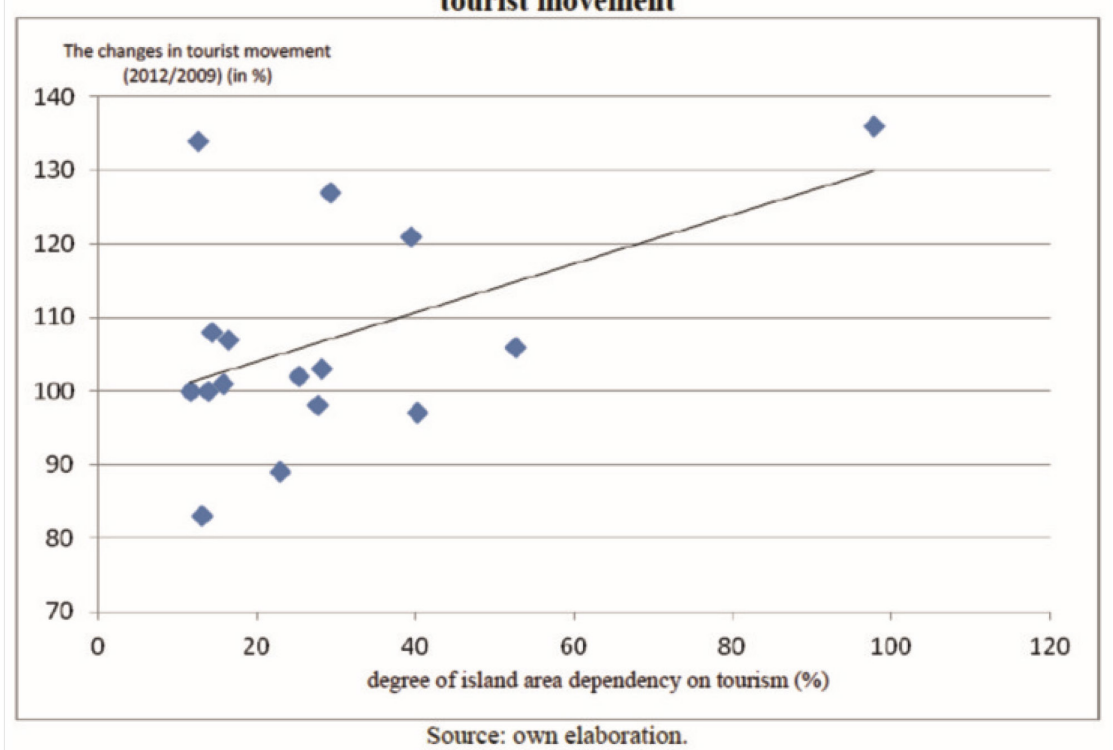

2 - degree of island area dependency on tourism and changes in tourist expenditures

$\mathrm{y}=0.271 \mathrm{x}-8.248$

$\mathrm{y}$-changes in tourist expenditures $\mathrm{x}$ - degree of

island area dependency on tourism

Linear regression analysis statistically significant at level: 0.115 for A and 0.174 for B.

Fig. 2 Linear regression for degree of island area dependency on tourism and

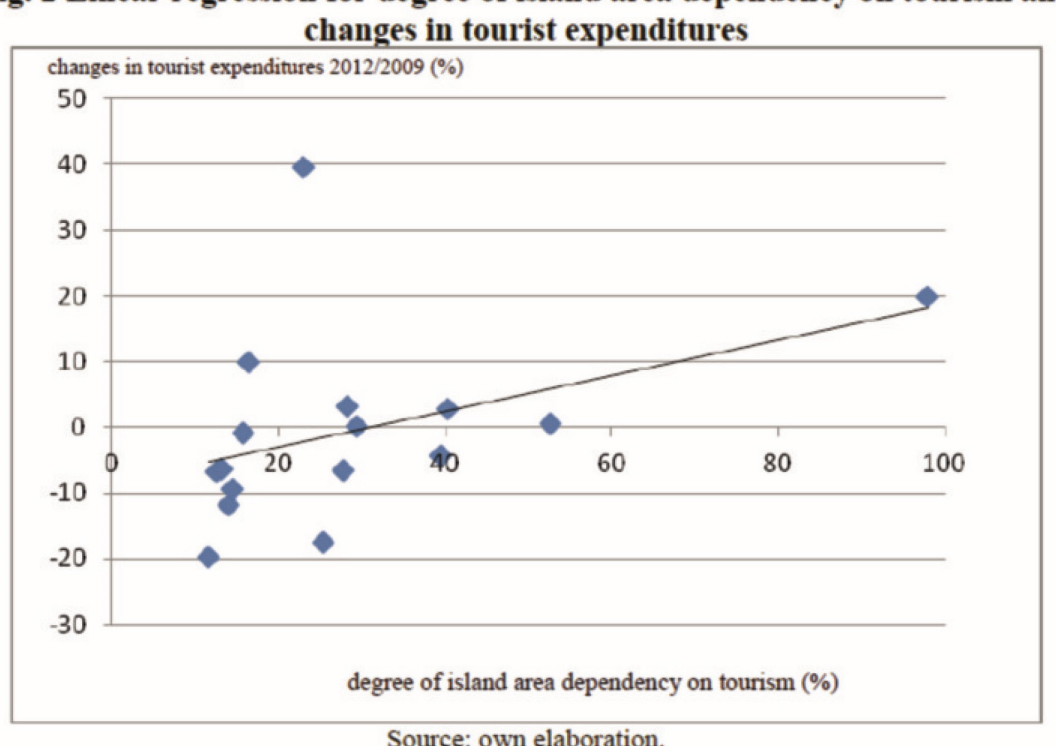




\section{3 - degree of diversification of incoming tourism markets and changes in} expenditures

$y=-0.325 x+8.258 y$-changes in expenditures $x$ - degree of diversification of incoming tourism markets

Linear regression analysis statistically significant at level: 0.101 for A and 0.206 for B.

Fig. 3 Linear regression for degree of diversification of incoming tourism markets and changes in expenditures

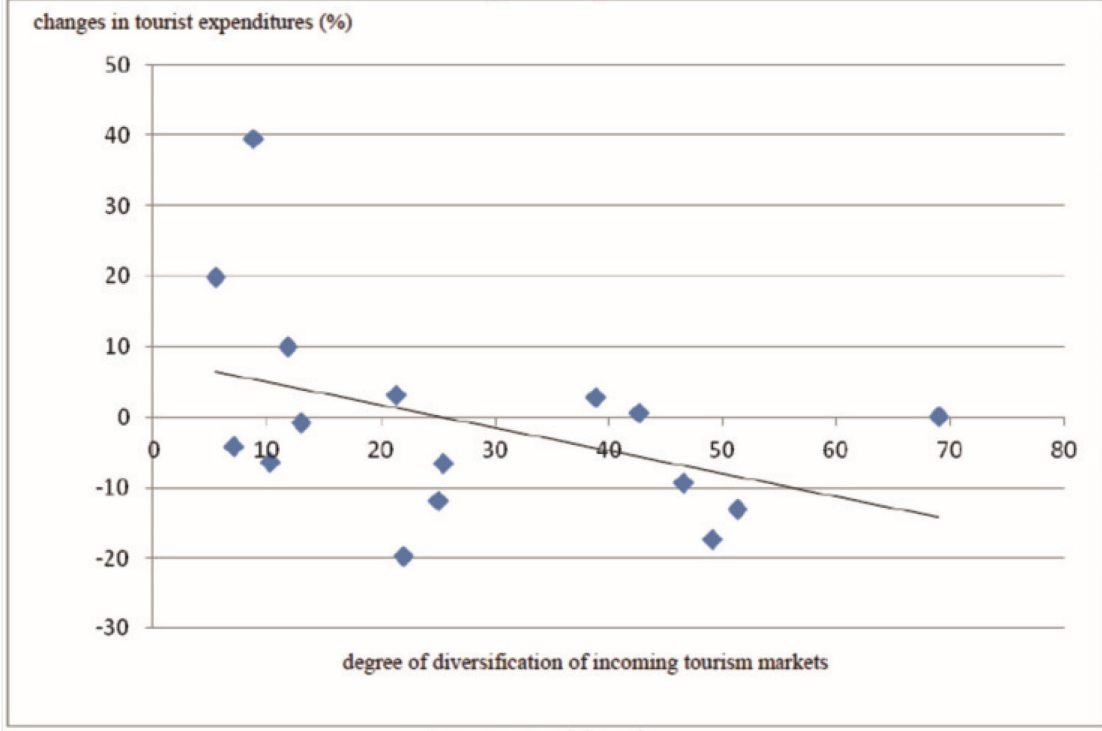

Source: own elaboration.

4 - tourism expenses per tourist and changes in tourist movement

$\mathrm{y}=0.012 \mathrm{x}+97.422 \mathrm{y}$-changes in tourist movement $\mathrm{x}$ - tourism expenses per tourist Linear regression analysis statistically significant at level: 0.000 for A and 0.050 for B.

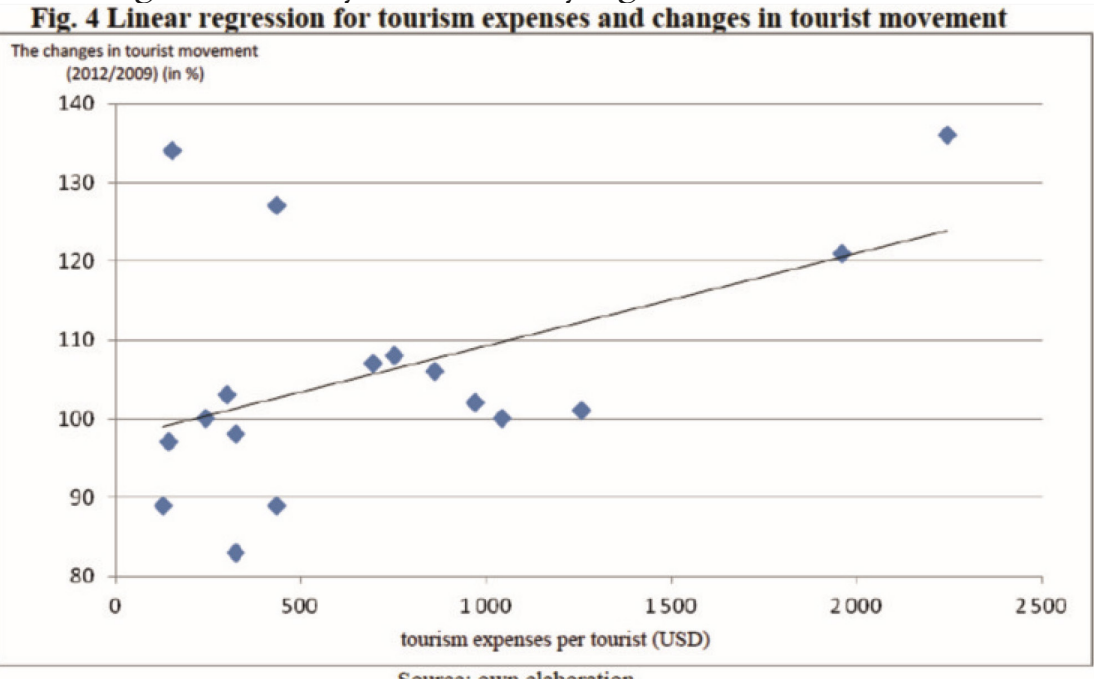

5 - tourism expenses per tourist and changes in employment in tourism industry $y=-0.008 x+6.161$

$\mathrm{y}$-changes in employment in tourism industry

$\mathrm{x}$ - expenses per tourist

Linear regression analysis statistically significant at level: 0.185 for A and 0.280 for B. 
Fig.5 Linear regression for tourism expenses per tourist and changes in employment in tourism industry

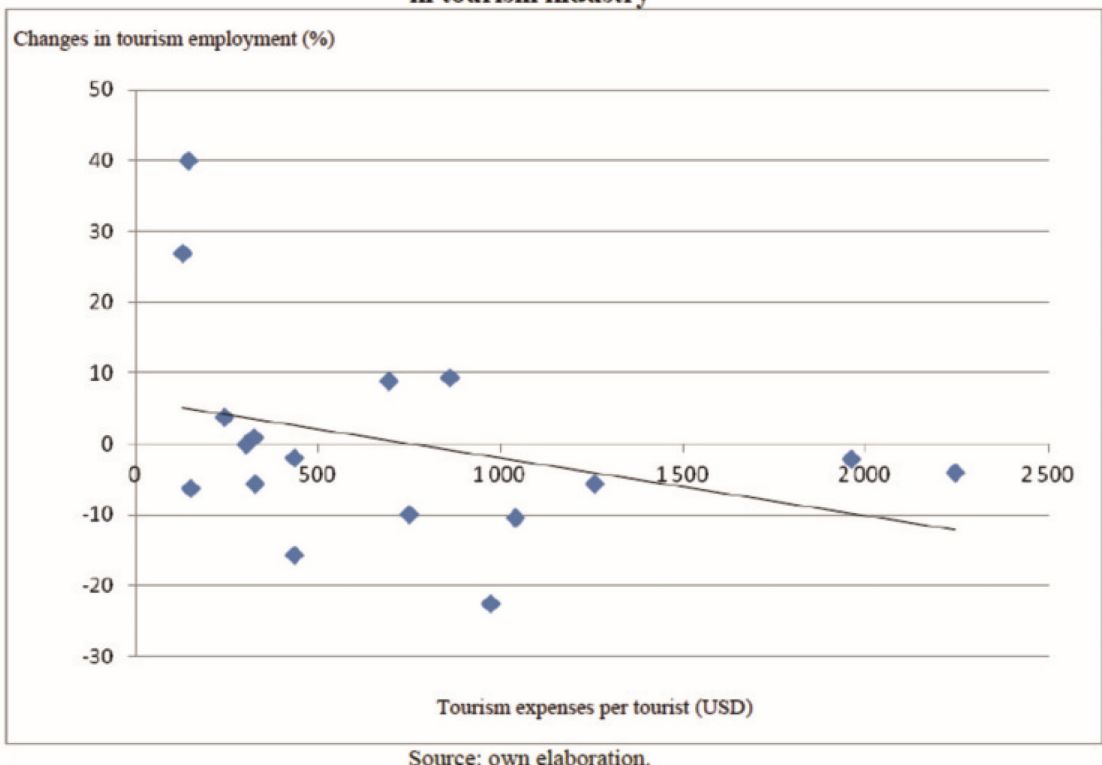

Outcomes of the statistical analysis

As a result of the statistical analysis and based on the results of the Spearman rank correlation and the Kendall correlation, the following hypotheses regarding tourism were verified:

1. The length of time a state has been independent influenced reaction to the global financial crisis: The hypothesis has been confirmed for changes in tourism and employment in tourism. The longer a given state has been independent, the better the reaction of the tourism sector to the global financial crisis.

2. The degree to which an island area was dependent on tourism influenced reaction to the global financial crisis (the relation of income from tourism and GDP): The hypothesis has been confirmed for three variables (changes in tourism, employment in tourism, and tourism expenditure). The larger the income from tourism, the better the situation of an island territory regarding the crisis.

3. The level of dependence on main markets for incoming tourism influenced reaction to the global financial crisis (the more dependent a given island area was on, for example, one main market, the worse the situation during the crisis, and the more diverse the markets for incoming tourism, the better): The hypothesis was confirmed.

4. The level of dependence on the main market influenced reaction to the global financial crisis; the lower, the better for a given island area: The hypothesis has been partially confirmed. There is no dependence for changes in tourism, but there is a relationship for changes in employment in tourism and tourism expenditure.

5. The level of dependence of a given island area on European markets influenced reaction to the global financial crisis; the more dependent, the better for a given island area: The hypothesis was not confirmed. Actually, this dependence, both for the Kendall and Spearman rank correlations, is nearly zero for changes in tourism and employment in tourism, but for changes in tourism expenditure the dependence is low.

6. The level of dependence of a given island area on North American and South American markets influenced reaction to the global financial crisis; the larger it was, the worse it was for the island areas (the crisis affected the American market greatly): The hypothesis was not confirmed. There is no dependence between reaction to the crisis in tourism and tourism expenditure on the one hand and the level of dependence of island territories on North American and South American markets as calculated by the Spearman and Kendall rank correlation coefficients on the other. 
7. The duration of flights to and from the main market (expressed in hours) influenced reaction to the global financial crisis; the shorter they were, the better the reaction of a given island territory to the crisis: The hypothesis was not confirmed. There is no correlation between the three analysed variables.

8. Tourism expenditure per tourist influenced reaction to the global financial crisis; the higher it was, the better the reaction of an island territory to the crisis: The hypothesis has been partially confirmed. A dependence is registered for tourism arrivals, but not for changes in tourism employment or tourism expenditure.

9. An island area's level of economic development influenced reaction to the global financial crisis: The hypothesis has been partially confirmed. No such dependence for tourism or employment in tourism was observed; only in the case of tourism expenditure was a weak dependence observed.

10. The quality of life on an island area measured by HDI index influenced reaction to the global financial crisis: The hypothesis has been only partially confirmed. The dependence measured by the Kendall rank correlation coefficient and the Spearman coefficient was negative and weak for tourism and tourism expenditure. There was no dependence for employment in tourism.

11. Increased governmental expenditure on tourism influenced reaction to the global financial crisis: The hypothesis was not confirmed for three variables (perhaps private investment in the tourism sector should be analysed instead of centralised public expenditure).

Moreover, it was possible to create linear regression analysis for: degree of island area dependency on tourism and changes in tourist movement; degree of island area dependency on tourism and changes in tourist expenditures; degree of diversification of incoming tourism markets and changes in tourist expenditures; tourism expenses per tourist and changes in tourist movement; tourism expenses per tourist and changes in employment in tourism industry. The biggest significance of the model was recorded for tourism expenses per tourist and changes in tourist movement.

The small sample (only 17 island territories) makes it difficult to generalise the results.

\section{Findings}

The biggest influences on the reaction of the 17 tourism islands to the global financial crisis, according to changes in tourism movement, were from:

1. degree of dependence on tourism (ratio of tourism income to GDP),

2. tourism expenditure per tourist, and

3. length of time for which a state has been independent.

The biggest influences on tourism employment were:

1. degree of the dependence on tourism,

2. length of time as an independent state, and

3. degree of diversification of markets for incoming tourism.

The biggest influences on tourist expenditure were:

1. degree of dependence on tourism,

2. degree of diversification of incoming tourism markets,

3. dominance of the main incoming tourism market,

4. dependence on European markets,

5. level of economic development, and

6. quality of life of residents (measured by HDI index).

This indicates that diversification of markets is an effective way to minimise economic crises and that independent countries reacted better to the financial crisis. Moreover, the countries which rely more on tourism had a better reaction to the global financial crisis. It is 
speculated that this is because they appreciated how much they needed to invest in marketing campaigns and to support enterprises which rely on the tourism market (that is the evidence of Maldives and Seychelles).

The degree of dependence on tourism was the main condition which had the strongest influence on three measures: changes in tourism movement, tourism employment, and tourist expenditures.

The second condition was degree of diversification of markets for incoming tourism. This ratio explained the resilience of island territories to the global economic crisis, in terms of tourism employment and tourist expenditure. Moreover, the use of the coefficient of diversification for incoming tourism for tourism purposes was a good way to explain the diversification of tourism sector incoming markets.

The third condition was the degree of dependence on tourism, as the factor which influenced two factors: tourism employment and tourist expenditure.

The following conditions influenced only on one measure (changes in tourism movement or changes in tourist expenditure): tourism expenditure per tourist, dominance of the main incoming tourism market, dependence on European markets, level of economic development, and quality of life of residents.

Moreover, degree of island area dependence on tourism was observed to have a mild influence on reaction to economic crisis in terms of tourist expenditures, while the degree of diversification of incoming tourism markets mildly influenced the reaction to economic crisis in terms of tourist expenditures. Those relations were the significant at the 0.05 level and, with care, can be generalised for bigger number of tourist islands.

\section{References}

Abdi, H. (2007). Kendall rank correlation. In N.J. Salkind (Eds.) Encyclopedia of Measurement and Statistics (pp. 508-510). Thousand Oaks (CA): Sage.

Air Passenger Market Analysis (2017). IATA. Retrieved from https://www.iata.org/economics Bianchi, R.V. (2004). Tourism restructuring and the politics of sustainability: a critical view from the European periphery (the Canary Islands). Journal of Sustainable Tourism, 12(6), 495-529. https://doi.org/10.1080/09669580408667251

Blake, A. \& Sinclair M.T. (2003). Tourism crisis management: US response to September 11. Annals of Tourism Research, 30(4), 818-832. https://doi.org/10.1016/S01607383(03)00056-2

Bremond, J., Couet, J.F., \& Salort, M.M. (2005). Kompendium wiedzy o ekonomii. Warszawa: Wydawnictwo Naukowe PWN.

Capó, J., Font, A.R., \& Nadal, J.R. (2007). Dutch disease in tourism economies: evidence from the Balearics and the Canary Islands. Journal of Sustainable Tourism, 15(6), 615-627. https://doi.org/10.2167/jost698.0

Coshall, J.T. (2000). Spectral analysis of international tourism flows. Annals of Tourism Research, 27(3), 577-589. https://doi.org/10.1016/S0160-7383(99)00081-X

Crompton, J., Lee, S., \& Shuster, T. (2001). A guide for undertaking economic impact studies: the springfest example. Journal of Travel Research, 40(1), 79-87. https://doi.org/10.1177/004728750104000110

Dwyer, L., Forsyth, P., \& Spurr R. (2004). Evaluating tourism's economic effects: new and old approaches. Tourism Management, 25(3), 307-317. https://doi.org/10.1016/S02615177(03)00131-6

Dwyer, L. \& Forsyth, P. (1993). Assessing the benefits and costs of inbound tourism. Annals of Tourism Research, 20(4), 751-768. https://doi.org/10.1016/0160-7383(93)90095-K

Dziedzic, E. (Ed.) (2012). Reagowanie branży turystycznej na sytuacje kryzysowe. Warszawa: Szkoła Główna Handlowa. 
Dziedzic, T., Łopaciński, K., Saja, A., \& Szegidewicz, J. (2010). Polska gospodarka turystyczna w okresie światowego kryzysu. Warszawa: Instytut Turystyki, Polska Agencja Rozwoju Turystyki.

Fletcher, J. (1994). Input-output analysis. In S.F. Witt \& L. Moutinho (Eds.), Tourism marketing and management handbook (pp. 480-484). London: Prentice-Hall.

Geise, P. (2009). Różne oblicza kryzysu w turystyce. Trendy i tendencje. Hospitality,

Kwartalnik Menedżerów Hotelarstwa, 3(29), 42-59.

Goodrich, J.N. (2001). September 11, 2001 attack on America: a record of the immediate impacts and reactions in the USA travel and tourism industry. Tourism Management, 23(6), 573-580. https://doi.org/10.1016/S0261-5177(02)00029-8

Grydehøj, A., (2011). Making the most of smallness: economic policy in microstates and subnational island jurisdictions. Space and Polity, 15(3), 183-196. https://doi.org/10.1080/13562576.2011.692578

Gwosdz, K., Ciechowski, M., \& Micek, M. (2010). Ekonomiczne podstawy funkcjonowania i rozwoju gospodarki miast. In B. Domański \& A. Noworól (Eds.), Badanie funkcji, potencjałów i trendów rozwojowych miast w województwie małopolskim (pp. 120-140). Kraków: Instytut Geografii i Gospodarki Przestrzennej, Uniwersytet Jagielloński.

d'Hauteserre, A.M., \& Funck, C. (2016). Innovation in island ecotourism in different contexts: Yakushima (Japan) and Tahiti and its Islands. Island Studies Journal, 11(1), 227-244.

Huang, J.H., \& Min, J.C.H. (2002). Earthquake devastation and recovery in tourism: the Taiwan case. Tourism Management, 23(2), 145-154. https://doi.org/10.1016/S0261-5177(01)00051-6

IndexMundi (2017). IndexMundi. Retrieved from https://www.indexmundi.com

Jędrusik, M. (2014). The elusive sustainable development of small tropical islands. Miscelanea Geographica Regional Studies on Development, 18(3), 26-30.

https://doi.org/10.2478/mgrsd-2014-0026

Jerczyński, M. (1973). Zagadnienia specjalizacji bazy ekonomicznej większych miast w Polsce. Studia nad strukturą funkcjonalą miast. Prace Geograficzne IG PAN, 97, 74-83.

Kaczmarska, A. (2014). Wybrane czynniki rozwoju turystyki. Kategorie i teorie ekonomiczne oraz polityka gospodarcza. Studia Ekonomiczne/Uniwersytet Ekonomiczny w Katowicach, 176, 201-215.

Karampela, S., Kizos, T., \& Spilanis, I. (2016). Evaluating the impact of agritourism on local development in small Island. Island Studies Journal, 11(1), 161-176.

Kim, H.Y., Chen, M.H., \& Jang, S.S. (2006). Tourism expansion and economic development: the case of Taiwan. Tourism Management, 27(5), 925-933. https://doi.org/10.1016/j.tourman.2005.05.011

Kokkranikal, J., Mclellan, R., \& Baum, T. (2003). Island Tourism and Sustainability: A Case Study of the Lakshadweep Islands. Journal of Sustainable Tourism, 11(5), 426-447. https://doi.org/10.1080/09669580308667214

Kotler, P. \& Caslione, J.A. (2009). Chaos. Zarzq̨dzanie i marketing w erze turbulencji. Warszawa: MT Biznes.

Law, A., Delacy, T., \& Mcgrath, M. (2016). A green economy indicator framework for tourism destinations. Journal of Sustainable Tourism, 25(10) ,1434-1455. https://doi.org/10.1080/09669582.2017.1284857

Lewis, D., Joseph, C.J., \& Roach, K.Q. (2009). The implications of the current global financial/economic crisis on integration: the Caribbean experience. Retrieved from https://studylib.net/doc/8053314/the-implications-of-the-current-global-financial-economic

Lim, C. (1999). A meta-analytic review of international tourism demand. Journal of Travel Research, 37(3), 273-284. https://doi.org/10.1177/004728759903700309

Nunkoo, R., Gursoy, D., \& Juwaheer, T.D. (2010). Island residents' identities and their support for tourism: an integration of two theories. Journal of Sustainable Tourism, 18(5),

675-693. https://doi.org/10.1080/09669581003602341 
Okumus, F., \& Karamustafa, K. (2005). Impact of an economic crisis: evidence from Turkey. Annals of Tourism Research, 32(4), 942-961. https://doi.org/10.1016/j.annals.2005.04.001

Pizam, A., \& Fleischer, A. (2002). Severity versus frequency of acts of terrorism: which has a larger impact on tourism demand? Journal of Travel Research, 40, 337-339.

Podhorodecka, K. (2014). Impact of tourist and one-day visitor arrivals on economic growth: case study of the Cayman Islands. Miscelanea Geographica Regional Studies on Development, $18(3), 16-25$.

Podhorodecka, K. (2008). Turystyka na wyspach strefy międzyzwrotnikowej. Zróżnicowanie roli gospodarczej i jego uwarunkowania (Doctoral thesis). Uniwersytet Warszawski, Warszawa, Poland.

Prideaux, B. \& Witt S. (2000). The impact of the Asian financial crisis on Australian tourism. Asia Pacific Journal of Tourism Research, 5(1), 1-7.

Reddyis, M.V. (2013). Global tourism and travel industry: performance during the double dip recession and recommendations for transitions to a green economy. The World Financial Review. Retrieved from https://www.worldfinancialreview.com/?p=977

Rucińska, D. \& Lechowicz, M. (2014). Natural hazard and disaster tourism. Miscellanea Geographica: Regional Studies on Development, 18(1). 17-25.

https://doi.org/10.2478/mgrsd-2014-0002

Ryan, C. (1993). Crime, violence, terrorism and tourism: an accidental or intrinsic relationship? Tourism Management, 14(3), 173-183. https://doi.org/10.1016/0261-5177(93)90018-G

Scheyvens, R., \& Momsen, J. (2008). Tourism in small island states: from vulnerability to strengths. Journal of Sustainable Tourism, 16(5), 491-510. https://doi.org/10.1080/09669580802159586

Shareef, R. \& McAleer, M. (2005). Modeling international tourism demand and volatility in small island tourism economies. International Journal of Tourism Research, 7, 313-333. https://doi.org/10.1002/jtr.538

Tiago, T., Delgada, P., Couto, J.P., \& Tiago, F. (2016). Different shades of green on small islands. Island Studies Journal, 11(2), 601-618.

Tiago, M.T., Tiago, F.G., \& Amaral, F.E. (2015). Food experiences: the oldest social network. Strategic Innovative Marketing. 4th IC-SIM, Mykonos, Greece 2015, 435-444. Retrived from https://link.springer.com/chapter/10.1007/978-3-319-33865-1 54

United Nations Development Programme (2016). Human development data (1990-2015). Retrieved from https://www.hdr.undp.org/en/data

World Bank (2017). World Bank open data. Retrieved from www.data.worldbank.org

World Tourism Organization (2010). UNWTO world tourism barometer, 8(1). Retrieved from https://www2.unwto.org/

World Travel \& Tourism Council (2015). Travel \& tourism economic impact 2015. London: World Travel \& Tourism Council, London.

Vanegas, S., \& Croes, R.R. (2000). Evaluation of demand: US tourists to Aruba. Annals of Tourism Research, 27(4), 946-963. https://doi.org/10.1016/S0160-7383(99)0011

Walsh, B. (2015). No, the rich have not gotten poorer since the financial crisis. BUSINESS HUFFPOST, 18 February. https://www.huffingtonpost.com/2015/02/17/inequalityupshot-new-york-times n 6702264. html

Wang, T. (2009). The impact of crisis events and macroeconomic activity on Taiwan's international inbound tourism demands. Tourism Management, 30, 75-82. https://doi.org/10.1016/j.tourman.2008.04.010

Winiarski, R. \& Zdebski, J. (2008). Psychologia turystyki. Warszawa: Wydawnictwa Akademickie i Profesjonalne.

Wites, T. (2009). Peripherality of the Kuril Islands: a development barrier or a development factor? Asia and Pacific Studies, 6, 81-95.

Zdon-Korzeniowska, M., \& Rachwał, T. (2011). Turystyka w warunkach światowego kryzysu gospodarczego. Prace Komisji Geografii Przemysłu, 18, 116-128. 